\title{
Antimicrobial and Antioxidative Activities of Peptides from Goat Milk Hydrolyzed with Various Protease
}

\author{
Kusumaningtyas $\mathrm{E}^{1,2}$, Widiastuti $\mathrm{R}^{1}$, Kusumaningrum $\mathrm{HD}^{2}$, Suhartono $\mathrm{MT}^{2}$ \\ ${ }^{1}$ Indonesian Research Center for Veterinary Science, RE Martadinata 30 St. Bogor \\ ${ }^{2}$ Department of Food Science and Technology, Faculty of Agricultural Engineering and Technology, \\ Bogor Agricultural University, Darmaga St. PO BOX 220 Bogor, 16002 \\ E-mail: enikusuma@yahoo.com; mthenawidjaja@yahoo.com
}

(received 16-06-2016; revised 13-07-2015; accepted 28-08-2015)

\begin{abstract}
ABSTRAK
Kusumaningtyas E, Widiastuti R, Kusumaningrum HD, Suhartono MT. 2015. Aktivitas antimikroba dan antioksidan peptida hasil hidrolisis susu kambing dengan berbagai protease. JITV 20(3): 175-183. DOI: http://dx.doi.org/10.14334/jitv.v20i3.1184

Susu mempunyai nilai nutrisi tinggi dan mengandung protein sebagai sumber peptida bioaktif yang berguna bagi kesehatan. Penelitian ini bertujuan untuk mengeksplorasi potensi peptida bioaktif dari susu kambing sebagai antimikroba dan antioksidan. Susu dihidrolisis menggunakan enzim tripsin, kimotripsin, pepsin atau protease Bacillus sp. E.13. Peptida yang diperoleh dipilah untuk aktivitas antimikroba dengan mencampurkan peptida dan bakteri Staphylococcus aureus, Listeria monocytogenes, Salmonella thyphimurium dan Escherichia coli sebanyak $10^{6} \mathrm{CFU} / \mathrm{mL}$ dan diinkubasi pada suhu $37^{\circ} \mathrm{C}$ selama 2 jam dan ditumbuhkan pada Mueller Hinton agar. Aktivitas antimikroba ditentukan dengan membandingkan jumlah koloni bakteri yang tumbuh pada cawan dengan dengan jumlah koloni bakteri kontrol tanpa penambahan peptida. Aktivitas antioksidan ditentukan melalui uji 2, 2'-azino-bis (3-ethylbenzthiazoline-6-sulphonic acid (ABTS) dan 2,2-diphenyl-1-picrylhydrazyl (DPPH). Aktivitas antimikroba terlihat pada peptida hasil hidrolisis susu kambing oleh pepsin pada suhu $37^{\circ} \mathrm{C}, \mathrm{pH} 2$ selama 90 menit dan protease Bacillus sp. E. 13 pada suhu $55^{\circ} \mathrm{C}$, pH 11 selama 30 and 60 menit tetapi aktivitas tersebut tidak terdeteksi pada peptida hasil hidrolisis protein dengan tripsin dan kimotripsin. Peptida dari hidrolisis protein oleh protease Bacillus sp. E.13 dapat menghambat Listeria monocytogenes, Salmonella thyphimurium dan Escherichia coli sampai 5 siklus log. Peptida antimikroba tersebut juga dapat meredam radikal ABTS sampai 86\% dan radikal DPPH 9\% pada konsentrasi $68 \mu \mathrm{g}$ protein/mL. Hasil tersebut mengindikasikan bahwa protein susu kambing yang dihidrolisis dengan protease Bacillus sp. E.13 berpotensi sebagai antimikroba sekaligus sebagai antioksidan.
\end{abstract}

Kata Kunci: Susu Kambing, Peptida, Antimikroba, Antioksidan

\begin{abstract}
Kusumaningtyas E, Widiastuti R, Kusumaningrum HD, Suhartono MT. 2015. Antimicrobial and antioxidative activities of peptides from goat milk hydrolyzed with various protease. JTTV 20(3): 175-183. DOI: http://dx.doi.org/10.14334/jitv.v20i3.1184

Milk is highly nutritious food containing protein as a good source of bioactive peptide that beneficial for health. This research was aimed to explore potency of bioactive peptide derived from goat milk as an antimicrobial and antioxidant. Milk was hydrolyzed by trypsin, chymotrypsin, pepsin, or protease Bacillus sp. E.13. The peptides obtained were screened for antimicrobial activities through incubation with Staphylococcus aureus, Listeria monocytogenes, Salmonella thyphimurium and Escherichia coli at $10^{6} \mathrm{CFU} / \mathrm{mL}$ at $37^{\circ} \mathrm{C}$ for two hours and plated on Mueller Hinton agar. Antimicrobial activities were determined by comparing the total bacterial colonies to that of bacterial control without peptides addition. Oxidative activity was determined by 2.2'-azino-bis (3-ethylbenzthiazoline-6-sulphonic acid (ABTS) and 2.2-diphenyl-1-picrylhydrazyl (DPPH) assays. Antimicrobial activities were shown in peptides produced from hydrolysis of goat milk protein by pepsin at $37^{\circ} \mathrm{C}$, $\mathrm{pH} 2$ for $90 \mathrm{~min}$ and by Bacillus sp. E. 13 protease at $55^{\circ} \mathrm{C}, \mathrm{pH} 11$ for 30 and $60 \mathrm{~min}$ but the activities were not detected in peptides from hydrolysis by trypsin and chymotrypsin. Peptide from protein hydrolysis by Bacillus sp. E.13 protease could inhibit Listeria monocytogenes, Salmonella thyphimurium and Escherichia coli up to 5 log cycles. The antimicrobial peptides could scavenge ABTS radical up to $86 \%$ and DPPH radical up to $9 \%$ at $68 \mu \mathrm{g}$ protein $/ \mathrm{mL}$. Results indicated that goat milk protein hydrolyzed by Bacillus sp. E.13 protease is potential as antimicrobes and antioxidant.
\end{abstract}

Key Words: Goat Milk, Peptide, Antimicrobe, Antioxidant

\section{INTRODUCTION}

Milk is highly nutritious food characterized by its amino acid profile balance. Concentration and composition of milks produced by each mammal are different depending on physiology and structure needed by the mammal's infants (Potocnik et al. 2011) affecting its essential amino acid and bioactive peptides 
contents. The bioactive peptides from cow milk have been reported could be antimicrobials, antioxidants, antihypertensives, and antithrombotics and some of them have multi functions (Lopez-Exposito et al. 2007). Amino acid sequences of proteins from cow and goat milks have the similarity which may express similarity in their bio-activities. Nevertheless, variation of amino acids from those species brings through variation in the bio-activaties.

Besides the amino acid sequence, the enzyme specificity used to hydrolyze protein was another factor for bioactive peptide produced (Pihlanto 2006). Bioactive peptides are mostly obtained through activity of indigenous protease or from enzyme intentionally added. Each enzyme has different substrate specificity and hydrolysis different amino acid sequence that produces different peptide fragments with certain amino acid sequence and bioactivity. Hydrolysis conditions such as $\mathrm{pH}$, temperature, and hydrolysis time determine the length of peptide sequences those also affects their activities. In this study, the goat milk protein was hydrolyzed by enzymes, and then antimicrobial and antioxidant activities of peptides produced were determined.

Antioxidant is defined as a substance in a small concentration that inhibit substrate oxidation (Halliwell 1990). The cell oxydation may produce reactive oxygen species (ROS) those attack macromolecules such as membrane lipida, protein and DNA and cause the pathogenesis of hypertension and stroke (Greig et al. 2010). Excessive nitric oxide (NO) produced during inflammation process affect pathologic problems to animal or human cells (Kawanishi et al. 2006). Antioxidant has a role to decrease the negative effects.

Bioactive peptides from hydrolyzation of goat milk by human gastrointestinal enzyme produced antibacterial and antioxidant compounds known to inhibit the growth of Escherichia coli K12, Bacillus cereus RT INF01, Listeria monocytogenes and Staphylococcus aureus ATCC 25923 (Almaas et al. 2011). For antioxidant activity, ability of scavenging free radical and chelating Fe ion were shown by peptide and casein of goat hydrolyzed milk using combination of neutral protease and alkali ( $\mathrm{Li}$ et al. 2013).

Enzymatic hydrolysis is an efficient technique generally used to produce bioactive peptide from natural protein (Madureira et al. 2010). Digestive enzymes used in this study were trypsin, chymotrypsin, pepsin, and protease from Bacillus sp. E.13. The digestive enzymes have been used to hydrolyze cow milk protein to produce bioactive peptides (McCann et al. 2005). Bacillus sp. E.13 was high proteolytic bacterium isolated from Bogor horse milk. This study was aimed to explore the potency of goat milk produced the bioactive peptide as antimicrobial and antioxidant through enzymatic process.

\section{MATERIALS AND METHODS}

\section{Microorganism}

Bacillus sp. E.13 was used for production of protease, while microorganisms used for antibiotic assays were Staphylococcus aureus (ATCC 25923), Listeria monocytogenes (ATCC 15313), Escherichia coli (ATCC 25922) and Salmonella Typhimurium (ATCC 13311).

\section{Goat milk}

Milk of Etawa crossbread goat was obtained from Faculty of Animal Science, Bogor Agricultural University. Fresh milk fat was separated by centrifugation at $6000 \mathrm{~g}$ for 15 minutes and discarded, while whey and casein was remixed and hydrolyzed.

\section{Determination of protein concentration}

Determination of protein concentration was done using Bradford (Quick start TM Bradford protein assay, Bio-Rad Inc). Standard curve was made by reacting $5 \mu \mathrm{l}$ of Bovine serum albumin (BSA) in various concentrations with $95 \mu \mathrm{l}$ Bradford solution. The same treatment was done to samples and distilled water as a blank. The reactions were incubated at room temperature for 5 minutes and their absorbance were measured in $\lambda=600 \mathrm{~nm}$ (Labsystems, original Multiscan Ex).

\section{Production of Bacillus sp. E. 13 protease}

Bacillus sp. E.13 was grown in Luria bertani broth consisting of $0.05 \%$ skimmed milk incubated at $37^{\circ} \mathrm{C}$ for 24 hours. Culture was centrifuged at $3500 \mathrm{~g}$ for 15 minutes and enzyme in the supernatant was precipitated with $50 \%$ ammonium sulfate according to Rowan et al (1990). After overnight incubation at $4^{\circ} \mathrm{C}$ pellet of the enzyme was collected by centrifugation at $1000 \mathrm{~g}$ for 15 minutes. The pellet was wind-dried and stored at $-20^{\circ} \mathrm{C}$ before used or dissolved in PBS pH 7.4 with ratio 1:2 for direct use to hydrolyze milk protein.

\section{Determination of enzyme activity}

Protease activity determination of enzymes was assayed using the method of Bergmeyer \& Grassel (1983) by reacting $250 \mu \mathrm{L} 2 \%(\mathrm{w} / \mathrm{v})$ casein with $50 \mu \mathrm{L}$ enzyme and $250 \mu \mathrm{L}$ PBS $0.05 \mathrm{M} \mathrm{pH}$ 7. The mixture was incubated at $37^{\circ} \mathrm{C}$ for 10 minutes and then $500 \mu \mathrm{L}$ TCA $0.2 \mathrm{M}$ was added and incubated again at $37^{\circ} \mathrm{C}$ for 10 minutes, then was centrifuged by $2000 \mathrm{~g}$ for 10 minutes. Supernatant was separated and $375 \mu \mathrm{L}$ of the supernatant was mixed with $1250 \mu \mathrm{L} \mathrm{Na}_{2} \mathrm{CO}_{3} 0.4 \mathrm{M}$ 
and added with $250 \mu \mathrm{L}$ Folin Ciolcateau reagent with $1: 2$ dilution and incubated at $37^{\circ} \mathrm{C}$ for 20 minutes. Absorption was measured at $\lambda 578 \mathrm{~nm}$. Distilled water was used as a blank and $5 \mathrm{mM}$ tyrosine solution was used as standard. One unit of activity was defined as amount of enzyme which could produce $1 \mu \mathrm{mol}$ tyrosine per minute at assay condition.

\section{Hydrolysis of milk protein}

Hydrolytic condition of trypsin (T1426, SigmaAldrich Co, 10.000 BAEE unit/mg protein), chymotrypsin (C4129, Sigma-Aldrich Co, 40 unit/mg protein) and pepsin (P7000, Sigma-Aldrich Co, 250 unit/mg solid) was carried out based on instruction of each enzyme namely: trypsin was at $37^{\circ} \mathrm{C}, \mathrm{pH} 8$ for 120 minutes, in the ratio between enzyme and substrate of $1: 100$; chymotrypsin was at $30^{\circ} \mathrm{C}, \mathrm{pH} 7.8$ for 120 minutes with enzyme and substrate ratio was 1:60; and pepsin was at $37^{\circ} \mathrm{C}, \mathrm{pH} 2$ for 60 minutes with enzyme and substrate ratio was 1:30. For protease of Bacillus sp. E.13, enzyme activity was 0.67 unit $/ \mathrm{mL}$ with enzyme and substrate ratio was 1:20. The hydrolysis was done at $55^{\circ} \mathrm{C}$ and pH 7 (Josephine et al. 2012) and pH 11 (Patel et al. 2006) for 30-60 minutes. Each peptide from the hydrolysis was centrifuged at $14000 \mathrm{~g}$ for 15 minutes until 3 layers formed. Transparentcolored center was collected for antimicrobial and antioxidant tests.

\section{Antimicrobial test}

Antimicrobial test was done using Staphylococcus aureus, Listeria monocytogenes, Salmonella thyphimurium and Escherichia coli. Screening was done using screening method by Lopez-Exposito et al. (2007), that was by mixing $100 \mu \mathrm{L}$ peptide with $100 \mu \mathrm{L}$ microbes at $10^{6} \mathrm{CFU} / \mathrm{mL}$ in microplates and incubated at $37^{\circ} \mathrm{C}$ for 2 hours. Then, $10 \mu \mathrm{L}$ of the mixture was dripped on Mueller Hinton agar and incubated at $37^{\circ} \mathrm{C}$ overnight. The result was positive if there is a bacterial growth inhibition. Every treatment was repeated 3 times. The next test was done by mixing $100 \mu \mathrm{L}$ peptide with $100 \mu \mathrm{L}$ bacteria at $10^{6} \mathrm{CFU} / \mathrm{mL}$ in microplates and incubated at $37^{\circ} \mathrm{C}$ for 2 hours. Then the mixture was diluted and grown on Mueller Hinton agar and incubated again at $37^{\circ} \mathrm{C}$ for 24 hours. Colonies of bacteria were counted.

\section{Antioxidant activity assay using ABTS [2, 2'-azino- bis (3-ethylbenzthiazoline-6-sulphonic acid)]}

Stock solution of $7.4 \mathrm{mM}$ ABTS was prepared in deionized water, while stock solution of potassium persulfate $2.4 \mathrm{mM}$. Before assays the reactant was prepared by mixing both stock solutions by $1: 1$ ratio.
Oxidation occurred when the mix solution kept in dark condition for 16-18 hours. The solution was diluted with deionized water to obtain absorbance by $1.1 \pm 0.02$ unit at $\lambda 405 \mathrm{~nm}$. Peptides at $100 \mu \mathrm{l}$ were mixed with $200 \mu 1$ ABTS radical solution in microplates and incubated for 10 minutes. The absorbance was read at $405 \mathrm{~nm}$. This method was carried out according to Thaipong et al (2006) with replacing cuvette with microplates. Standard curve was made by measuring antioxidant activity of vitamin $\mathrm{C}$ p.a at various concentrations. Determination of every sample activity was repeated 3 times.

\section{Antioxidant activity assay using DPPH (2.2- diphenyl-1-picrylhydrazyl)}

Antioxidant testing using DPPH was done based on modified combination methods of Thaipong et al. (2006) and Clarke et al. (2013). Ethanol 96\% was used for diluting DPPH at absorbance $1.1 \pm 0.05$ instead of methanol (Thaipong et al. 2006). The modification was carried out after preliminary test in both methanol and ethanol showed relatively similar. Peptides at $100 \mu \mathrm{l}$ in various concentrations were added with $200 \mu \mathrm{DPPH}$ and left for 30 minutes and the absorbance was measured at $\lambda=540 \mathrm{~nm}$ (Clarke et al. 2013). Standard curve was made by measuring the antioxidant activity of vitamin C p.a in various concentrations. Every sample was determined in triplicate.

Antioxidant activity in ABTS and DPPH test was calculated by the following equation:

$$
\text { Antioxidant activity (\%) }=\frac{(\text { Blank abs }- \text { Sample abs }) 100 \%}{\text { Blank abs }}
$$

where:

Blank abs = Was an absorbance of ABTS/DPPH solution

Sample abs = Was absorbance of samples (pepti des) reacted with $\mathrm{ABTS} / \mathrm{DPPH}$ minus abs of peptide as controls. The controls were prepared without ABTS/DPPH

Vitamin $\mathrm{C}$ equivalent was calculated based on standard curve of vitamin $\mathrm{C}$ antioxidant activity

\section{Profile of peptides using HPLC}

Selected peptide hydrolysates those had the best microbial activity incubated at 30 and 60 minutes were applied into HPLC C-18 column (5 $\mu \mathrm{m}, 4.6 \times 250 \mathrm{~mm}$, Xterra, Waters). Hydrolysates were eluted with gradient linear $5-45 \%(\mathrm{v} / \mathrm{v})$ of $0.1 \%$ trifuoroacetic acid (TFA) $(\mathrm{v} / \mathrm{v})$ in acetone nitrile $(\mathrm{ACN})$ (solvent $\mathrm{A})$ in $0.1 \%$ TFA $(\mathrm{v} / \mathrm{v})$ in the deionized water (solvent B). HPLC system was equilibrated by $95 \%$ of solvent B for 5 minutes, followed by the gradient solvent for 16 minutes to elute 
peptides, then re equilibrated with solvent $\mathrm{B}$ for 5 minutes (McCann et al. 2005). Absorbance was measured at $\lambda=215 \mathrm{~nm}$.

\section{RESULTS AND DISCUSSION}

Data from Table 1 showed that only peptides from goat milk hydrolyzed with proteases of Bacillus sp. E.13 at $\mathrm{pH} 11$ and pepsin at 90 minutes incubation which inhibited bacterial growths. Filtered goat milk at $0.45 \mu \mathrm{m}$ as a control also showed negative inhibition that confirmed that only hydrolyzed milk peptides had antimicrobial activity. Using other enzymes and hydrolysis conditions also showed negative results. Inhibition of pepsin as protease might be influenced by the low $\mathrm{pH}$ condition, since the pepsin itself also showed inhibition, while other enzymes in neutral and alkali condition gave negative results. Further research should be carried out to determine whether the antimicrobial activity was from peptide produced or due to low $\mathrm{pH}$.

Peptides of goat milk hydrolyzed by trypsin and chymotrypsin did not inhibit the growth of any tested bacteria (Table 1). These data are in agreement by data reported by McCann et al. (2006) which using peptides of cow milk casein hydrolyzed by trypsin and chymotrypsin for 4 hours. Burris (2004) reported that cow milk casein hydrolyzed by trypsin and chymotrypsin in the same temperatures and $\mathrm{pH}$ hydrolysis as in this experiment but longer incubation time for five hours could inhibit the growth of $L$. monocytogenes. Addition of hydrolysis time as done by
Burris (2004) might cause further hydrolysis producing shorter peptides and higher antimicrobial activity.

In this experiment hydrolysis time was carried out according to the enzyme label, longer incubation time that produce more active peptides will be good to be evaluated. There is a possibility that difference sequence of amino acids of cow milk used by Burris (2004) with goat milk in this study resulted different antimicrobial activity. Peptide from goat milk hydrolyzed by pepsin for 90 minutes in this experiment only inhibited 1 log cycle against $S$. aureus, $L$. monocytogenes, E. coli and S. Typhimurium.

Further antimicrobial activity determination using colony form unts showed that peptides of goat milk hydrolyzed by protease Bacillus sp. E.13 for 30, 60 minutes only decreased CFU of $S$. aureus less than 1 $\log$ cycle, while for $L$. monocytogenes, E. coli and $S$. Typhimurium could decrease up to $5 \mathrm{log}$ cycles (Figure 2). Longer hydrolysis incubation time from 30 to 60 minutes did not affect CFU numbers.

Those results proved that protease from Bacillus sp. E.13 could potentially hydrolyze goat milk protein into antimicrobial peptides especially for L. monocytogenes, E. coli and S. Typhimurium which are Gram-positive and negative bacteria. Some Bacillus proteases are reported may be used to hydrolyze protein into antimicrobial peptides with high activity. Kent et al. (2012) reported that bovine casein fermented by $B$. cereus and B. thuringiensis inhibit Chronobacter sakazakii. Hydrolysis of goat milk casein using Bacillus sp. P45 produces antimicrobial peptides against $S$. enteritidis, E. coli, C. fimi and L. monocytogenes (Daroit et al. 2012).

Table 1. Antimicrobial activity of peptides from goat milk hydrolyzed with various enzymes, $\mathrm{pH}$, temperature and incubation time conditions

\begin{tabular}{|c|c|c|c|c|c|c|c|c|}
\hline \multirow{5}{*}{ Bacteria } & \multicolumn{8}{|c|}{ Antimicrobial Activity } \\
\hline & \multirow{3}{*}{$\begin{array}{c}\text { Trypsine } \\
37^{\circ} \mathrm{C} \\
\text { pH } 8 \\
\end{array}$} & \multirow{3}{*}{$\begin{array}{c}\text { Chymotrypsine } \\
30^{\circ} \mathrm{C} \\
\text { pH } 7.8 \\
\end{array}$} & \multirow{2}{*}{\multicolumn{2}{|c|}{$\begin{array}{l}\text { Pepsin } \\
37^{\circ} \mathrm{C}\end{array}$}} & \multicolumn{4}{|c|}{ Bacillus sp.E.13 Protease } \\
\hline & & & & & \multirow{2}{*}{\multicolumn{2}{|c|}{$\begin{array}{l}55^{\circ} \mathrm{C} \\
\mathrm{pH} 7\end{array}$}} & \multirow{2}{*}{\multicolumn{2}{|c|}{$\begin{array}{r}55^{\circ} \mathrm{C} \\
\mathrm{pH} 11\end{array}$}} \\
\hline & & & \multicolumn{2}{|c|}{$\mathrm{pH} 2$} & & & & \\
\hline & $120^{\prime}$ & $120^{\prime}$ & $60^{\prime}$ & $90^{\prime}$ & $30^{\prime}$ & 60 & 30 & $60^{\prime}$ \\
\hline S. aureus & - & - & - & + & - & - & + & + \\
\hline L monocytogenes & - & - & - & + & - & - & + & + \\
\hline E. coli & - & - & - & + & - & - & + & + \\
\hline S. typhimurium & - & - & - & + & - & - & + & + \\
\hline
\end{tabular}

+: positive result for antimicrobial activity

- : negative result for antimicrobial activity 

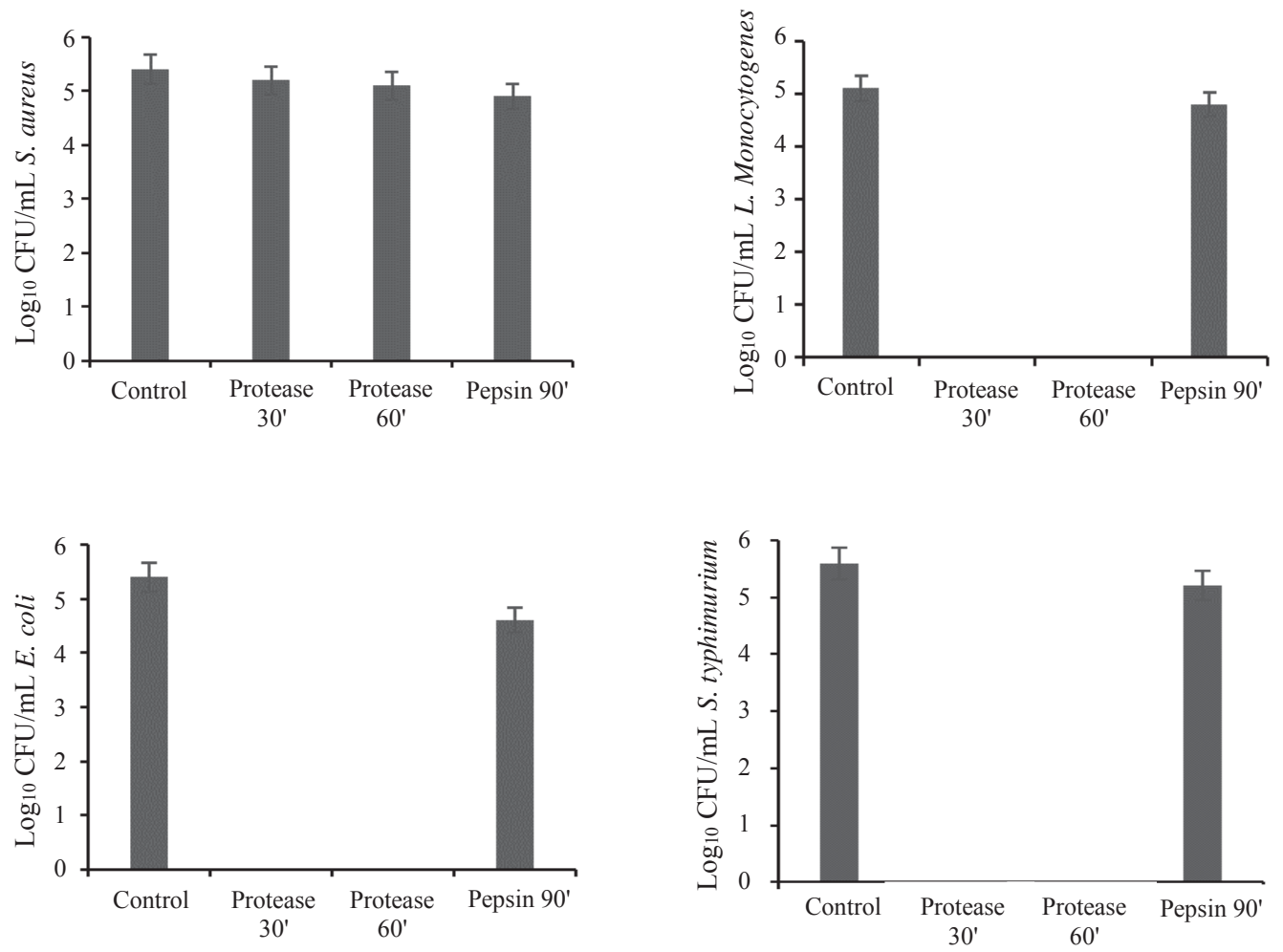

Figure 1. Number of CFU of bacteria from antimicrobial testes of milk goat peptides produced by hydrolysis with proteases of Bacillus sp. E. 13 at $55^{\circ} \mathrm{C} \mathrm{pH} 11$ for 30,60 minutes and pepsin at $37^{\circ} \mathrm{C} \mathrm{pH} 2$ for 90 minutes, respectively

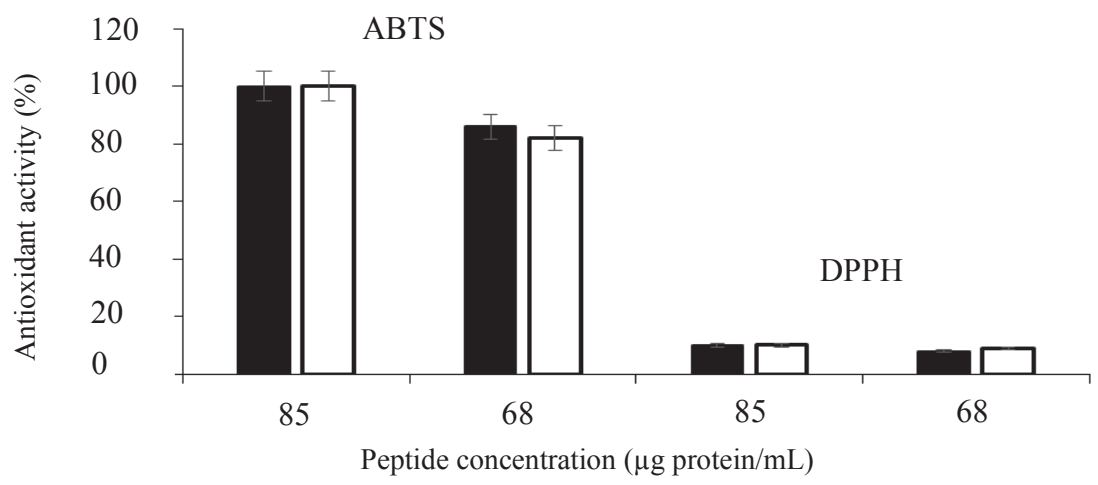

$30 \mathrm{~min}$ $60 \mathrm{~min}$

Figure 2. Antioxidant activities of peptides from goat milk hydrolyzed by protease Bacillus sp. E. 13 at $55^{\circ} \mathrm{C}$ pH 11 for 30 at 60 minutes at concentrations of 68 and $85 \mu \mathrm{g}$ protein $/ \mathrm{mL}$ against ABTS and DPPH

In this study, S. aureus was more resistant against antimicrobial peptide compared to other bacteria. There is possibility in this experiment that antimicrobial peptide formed pores in other bacteria cell membrane, broke the membrane and destroy the cells. Rigidity of cell wall in $S$. aureus persistents to turgor pressure up to 3-25 higher than that may be tolerated by the Gramnegative bacteria (Sato \& Feix 2006). That ability led 
the $S$. aureus relatively more resistant to antimicrobial activity. The bacterium is capable to produce an extracellular protease such as aureolysin which may breaks down the LL-37 antimicrobial peptide by hydrolyzing its C-terminal (Nawrocki et al. 2014).

Although L. monocytogenes is a gram-positive bacterium, its growth was inhibited by peptide from goat milk protein hydrolyzed by protease Bacillus sp. E.13 at $37^{\circ} \mathrm{C}$. Lopez-Solanilla et al. (2003) reported various susceptibilities of $L$. monocytogenes to antimicrobial peptides and influenced by their incubation temperatures. Its growth was highly inhibited by human defensin but slightly inhibited by protamine peptide, snakin, and magainin. Defensin peptide of potato was very affected in inhibition of the bacterium at $37^{\circ} \mathrm{C}$, but at $20^{\circ} \mathrm{C}$ the bacterium is resistant (Lopez-Solanilla et al. 2003).

Neutralization of ABTS and DPPH radicals was measured based on the ability of antioxidant to give hydrogen atom or to break down the radical compound (Correa et al. 2011). Antioxidant assays using ABTS is able to use in aqueous and organic solvent and not influenced by ionic strength. Therefore, the assay is applicable to determine hydrophilic or hydrophobic antioxidant (Prior et al. 2005). DPPH was usually used as ABTS for comparison, even though the ABTS usually gives higher antioxidant activity of various food materials (Floegel et al. 2011).

In ABTS assay, goat milk hydrolyzed by protease Bacillus sp. E.13 with protein concentration at 68 $\mu \mathrm{g} / \mathrm{mL}$ from 250 times dilution had antioxidant activity of $83 \%$ for 30 minutes hydrolysis and $86 \%$ for 60 minutes hydrolysis. The peptide neutralized ABTS radical up to $100 \%$ at 200 times dilution. The peptide from 30 minutes hydrolysis had higher activity to neutralize the ABTS radical than that of peptide from 60 minutes hydrolysis (Figure 2). Longer time hydrolysis of goat milk protein using protease Bacillus sp. E.13 decreased antioxidant activity. Antioxidant activity against ABTS increases after the milk casein hydrolyzed by protease compared with the one before hydrolysis (Rossini et al. 2009). Hydrolysis releases peptides in smaller size, increases ionized group, and discloses hydrophobic group which influence antioxidant activity (Sarmadi \& Ismail 2010). Correa et al. (2011) showed that the ability of casein hydrolyzed by protease of Bacillus sp. P7 to neutralize ABTS radical increasing by time incubation up to two hours, after that it becomes plateau.

Daroit et al. (2012) reported that antioxidant activity of peptide from goat milk casein hydrolyzed by protease Bacillus sp. P45 increased after 4 hours. That results was different with data from this experiment that decrease activity was observed in longer hydrolysis time from 30 up to 60 minutes. Sun et al. (2011) described that there was no correlation between hydrolysis time and antioxidant activity. Enzyme specificity on amino acid sequences to produce peptides more determine antioxidant activity than time of hydrolysis. Purification may increase antioxidant activity, if the process increase the concentration and purity of the active peptide. However, antioxidant activity may decrease if purification omits interaction between peptides in hydrolysate. Antioxidant activity was higher by mix peptides of HAHp1-2III (901.45 Da), HAHp1-2IV (872.37 Da and HAHp1-2V (1171.60 $\mathrm{Da}$ ) from half-fin ancovy protein than the singles (Song et al. 2014).

In DPPH assay, detected antioxidant activity was lower than that of ABTS assay. The difference may due to difference of DPPH and ABTS character. DPPH radical is more stable than ABTS radical resulting DPPH more dificult to be neutralized (Prior et al. 2005). $\mathrm{DPPH}$ also has narrow of reaction range than ABTS, therefore it need more peptide to reach the same antioxidant activity value with ABTS. However, they have similar value of vitamin $\mathrm{C}$ equivalent. For example, antioxidant activity of peptide from 30 minutes hydrolysis with concentration $35 \mu \mathrm{g}$ protein $/ \mathrm{mL}$ equal with $\pm 3 \mu \mathrm{g} / \mathrm{mL}$ of vitamin $\mathrm{C}$ to neutralize the ABTS radical and equal with ability of $\pm 2.55 \mu \mathrm{g} / \mathrm{mL}$ vitamin $\mathrm{C}$ to neutralize the DPPH radical.

Characterization of peptides using RP-HPLC is shown in Figure 3. Longer hydrolysis time at 2.5 minutes retention time increased more peptide from goat milk hydrolyzed by protease Bacillus sp. E.13. Peak for 30 minutes hydrolysis increased from $0.6 \mathrm{AU}$ into $1.35 \mathrm{AU}$ at 60 minutes hydrolysis. On the contrary, the peptide with 8-10 minutes of retention time decreased intensity from $0.80 \mathrm{AU}$ into $0.60 \mathrm{AU}$ respectively indicating a decrease of peptide concentration with 8-10 minutes of retention time.

The absorbance of the peptide hydrolysates was conducted at $215 \mathrm{~nm}$, the specific wavelength for peptides. Based on the chromatogram (Figure 3), character of the peptides from 30 and 60 hydrolysis are almost similar, indicating possibility of similar peptide composition. Change of peptide intencities may related to their bioactivities, but it need further anaysis such as amino acid sequencing using LC-MS/MS. Peptide from the 30 and 60 hydrolysis was dominated by more hydrophobic peptide in 6-10 min retention time.

According to Zhao et al. (2013), hydrophobicity of the peptide is correlated to antimicrobial activity since peptide with higher hydrophobicity resulted higher activity. Peptide from goat milk protein hydrolyzed by protease Bacillus sp. E.13 for 30 and 60 minutes with high antimicrobial is dominated by hydrophobic peptide that is able to inhibit bacterial growth up to $5 \log$ cycle. Althogh peptide with high hydrophobicity commonly showed high toxcicity, more over amino acid composition and distribution of the positive charge also 

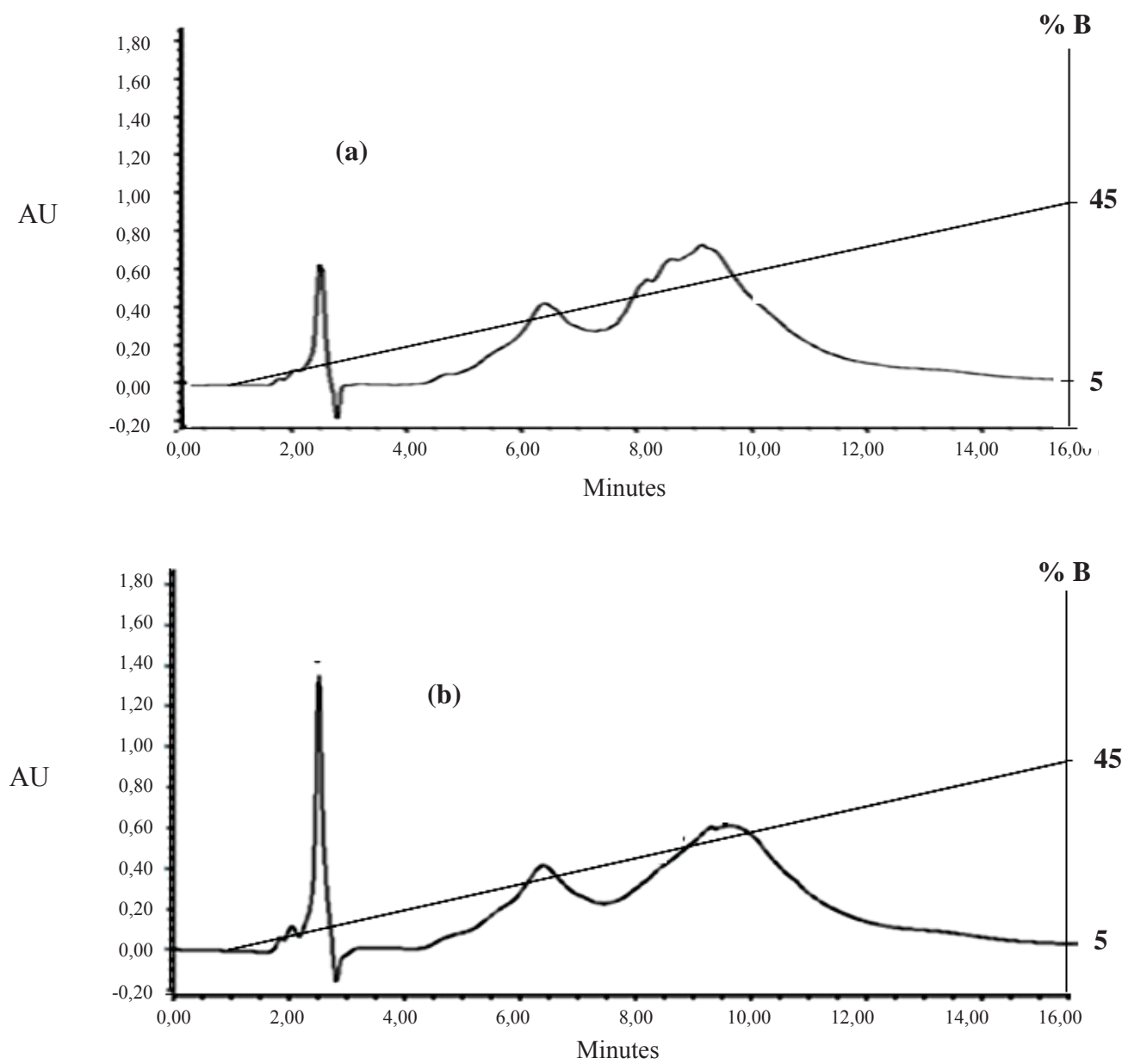

Figure 3. Profile of chromatogram of goat milk hydrolyzed by protease Bacillus sp at $55 \mathrm{o} \mathrm{C} \mathrm{pH} 11$ for 30 minutes (a) and 60 minutes (b), separation was done using RP-HPCL with gradient $0,1 \%$ TFA in deionized water (A soluble) and $0,1 \%$ trifluoroacetic acid (TFA) in acetonitrile (ACN) (B soluble) with water flowrate by $1 \mu 1 /$ minute at $\lambda 215 \mathrm{~nm}$

influence the toxicity determinant Yin et al (2012). For antioxidant activity, Ajibola et al. (2011) revealed that increasing hydrophobicity was related to antioxidant activity.

Peptides produced in this study may have multifunction as antimicrobial and antioxidant. Those peptides were highly potential to be applied to reduce the application of both antimicrobial drug and antioxidant suplement. The peptides were able to neutralize free radical excess due to interaction between peptides and bacteria cell. If the animal cell is infected by bacteria, interaction of animal and bacterial cells produces reactive oxygen species (ROS). High ROS concentration destroy host animal cells, even in excess condition cause the death (Sharma et al. 2012; Liu et al. 2013). Antimicrobial peptide such as diptericin had an important role in reducing ROS (Zhao et al. 2011).
Antimicrobial peptide which is simultaneously has antioxidant activity is observed in the amphibian skin. That peptide killed microbes in a short time and neutralized free radical formed in seconds (Yang et al. 2009). That kinetic makes the amphibian refuge from infection and oxidative stress that may occur. The multifunction activities of our peptide has to be optimized to be applied for feed supplement. Purification of the peptide might increase the activity.

\section{CONCLUSION}

Peptide from goat milk protein hydrolyzed by Bacillus sp. E.13 protease showed antibacterial and antioxidant activities. The peptides were able to inhibit L. monocytogenes, S. Typhimurium and E. coli up to 5 $\log$ cycles and inhibit $S$. aureus up to $1 \mathrm{log}$ cycle. The 
ability of the peptide as antimicrobial and antioxidant very potent to be applied as feed supplement.

\section{ACKNOWLEDGEMENT}

This study was funded by Indonesian Agency for Agricultural Research and Development, Ministry of Agriculture in National Budget of 2013 year Number 18023D and Directorate General of Higher Education, scheme of BOPTN 2013 Number 2013.089.521219.

\section{REFERENCES}

Ajibola CF, Fashakin JB, Fagbemi TN, Aluko RE .2011. Effect of peptide size on antioxidant properties of African yam bean seed (Sphenostylis stenocarpa) protein hydrolysate fractions. Int J Mol Sci. 12:66856702 .

Almaas H, Eriksen E, Sekse C, Comi I, Flengsrud R, Holm H, Jensen E, Jacobsen M, Langsrud T, Vegarud GE. 2011. Antibacterial peptides derived from caprine whey proteins, by digestion with human gastrointestinal juice. Br J Nutr. 106:896-905.

Bergmeyer HU, Bergmeyer J, Grassel M. 1983. Methods of enzymatic analysis Vol 2. Weinheim: Verlag Chemie.

Burris KP. 2004. Antimicrobial activity of trypsin and pepsin hydrolysates derived from acid-precipitated bovine casein (Thesis). University of Tennessee.

Clarke G, Ting KN, Wiart C, Fry J. 2013. High correlation of 2,2 -dipheenyl-1-picrylhydrazyl (DPPH) radical scavenging, ferric reducing activity potential and total phenolics content indicated redundancy in use of all three assay in use of all three assay to screen for antioxidant activity of extracts of plants from the Malaysian reinforest. Antioxidants. 2:1-10.

Correa AP, Daroit DJ, Coelho J, Meira SM, Lopes FC, Segalin J, Risso PH, Brandelli A. 2011. Antioxidant, antihypertensive and antimicrobial properties of ovine caseinate hydrolyzed with microbial protease. J Sci Food Agric. 91:2247-2254.

Daroit DJ, Correa APF, Canales MM, Coelho JG, Hidalgo ME, Tichota DM, Risso PH, Brandelli A. 2012. Physicochemical properties and biological activities of ovine caseinate hydrolysates. Dairy Sci Technol. 92:335-351.

Floegel A, Kim DK, Koo SI, Chun OK. 2011. Comparison of ABTS/DPPH assays to measure antioxidant capacity in popular antioxidant-rich US food. J Food Composition Anal. 24:1043-1048.

Greig JA, Shirley R, Graham D, Denby L, Dominiczak AF, Work LM, Baker A. 2010. Vascular-targeting antioxidant theraphy in a model of hypertension and stroke. J Cardiovasc Pharmacol. 56:642-650.

Halliwell B. 1990. How to characterize a biological antioxidant. Free Radic Res Commun. 9:1-32.
Josephine FS, Ramya VS, Devy N, Ganapa SB, Siddalingeswara KG, Venugopal N, Vishnawatha T. 2012. Isolation, production and characterization of protease from Bacillus sp isolated from soil sample. J Microbiol Biotech Res. 2:163-168.

Kawanishi S, Hiraku Y, Pinlaor S and Ma N. 2006. Oxidative and nitrative DNA damage in animal and patients with inflammatory disease in relation to inflammation-related carcinogenesis. Biol Chem. 387:365-372.

Kent RM, Guinane CM, O'Connor PM, Fitzgerald GF, Hill C, Stanton C, Ross RP. 2012. Production of the antimicrobial peptide caseicin A and B by Bacillus isolates growing on sodium caseinate. Lett Appl Microbiol. 55:141-148

Li Z, Jian A, Yue T, Wan Y, Su J. 2013. Purification and identification of five novel antioxidant peptides from goat milk casein hydrolysates. J Dairy Sci. 96:42424251 .

Liu W, Dong SL, Xu F, Wang XQ, Withers TR, Yu HD, Wang X. 2013. Effect of intracellular expression of antimicrobial peptide LL-37 on growth of Escherichia coli strain TOP10 under aerobic and anaerrobic conditions. Antimicrobiol Agent Chemother. 57:47074716 .

Lopez-Exposito I, Quiros A, Amigo L, Recio I. 2007. Casein hydrolysate as a source of antimicrobial, antioxidant and antihypertensive peptides. Lait. 87:241-249.

Lopez-Solanilla E, Gonzalez-Zorn B, Novella S, VazquezBoland JA, Rodriguez-Palenzuela. 2003. Susceptibillity of Listeria monocytogenes to antimicrobial peptides. FEMS Microbiol Lett. 226:101-105.

Madureira AR, Tavares T, omes AMP, Pintado ME, Malcata FX. 2010. Invited review: Physiological properties of bioactive peptides obtain from whey proteins. J Dairy Sci. 93:437-455

McCann KB, Shiell BJ, Michalski WP, Lee A, Wan J, Roginski H, Conventry MJ. 2005. Isolation and characterisation of antibacterial peptides derived from the $\mathrm{f}(164-207)$ region of bovine $\alpha \mathrm{S} 2$-casein. Int Dairy J. 15:133-143.

McCann KB, Shiell BJ, Michalski WP, Lee A, Wan J, Roginski H, Conventry MJ. 2006. Isolation and characterization of a novel antibacterial peptide from bovine $\alpha$ S1-casein. Int Dairy J. 16:316-323.

Nawrocki KL, Crispell EK, McBride SM. 2014. Antmicrobial peptide resistance mechanisms of gram positive bacteria. Antibiotics. 3:461-492.

Patel RK, Dodia MS, Joshi RH, Singh SP. 2006. Purification and characterization of alkaline protease from a newly isolated haloalkaliphilic Bacillus sp. Process Biochemistry. 41:2002-2009.

Pihlanto A. 2006. Antioxidative peptides derived from milk proteins. Int Dairy J. 16:1306-1314. 
Potocnik K, Gantner V, Kuterova K, Cividini A. 2011. Mare's milk: composition and protein fraction in comparison with different milk species. Mljekarstvo. 61:107-113.

Prior RL, Wu X, Schaich K. 2005. Standardized methods for determination of antioxidant capacity and phenolics in foods and dietary supplements. J Agric Food Chem. 53:4290-4302.

Rossini K, Noreña, CPZ, Cladera-Olivera F, Brandelli A. 2009. Casein peptides with inhibitory activity on lipid oxidation in beef homogenates and mechanically deboned poultry meat. LWT Food Sci Technol. 42:862867.

Rowan AD, Buttle DJ, Barrett AJ. 1990. The cysteine proteinases of the pineapple plant. Biochem J. 266:869875.

Sarmadi BH, Ismail A. 2010. Antioxidative peptides from food proteins: a review. Peptides. 31:1949-1956.

Sato H, Feix JB. 2006. Peptide-membrane interactions and mechanisms of membrane destruction by amphipathic $\alpha$-helical antimicrobial peptides. Biochem Biophysic Acta. 1758:1245-1256.

Sharma P, Jha AB, Dubey RS, Pessarakli M. 2012 Reactive oxygen species, oxidative damage, and antioxidative defense mechanism in plants under stressful condition. $\mathrm{J}$ Botany. ID 217037.
Song R, Wei R, Ruan G, Luo H. 2015. Isolation and identification of oxidative peptides from peptic hydrolysates of half-fin anchovy (Setipinna taty). LWT - Food Sci Technol. 60:221-229.

Sun Q, Shen H, Luo Y. 2011. Antioxidant activity of hydrolysate and peptide fractions derived from porcine hemoglobin. J Food Technol. 48:53-60.

Thaipong K, Boonprakob U, Crosby K, Cisneros-Zevallos L, Byrne DH. 2006. Comparison of ABTS, DPPH, FRAP, and ORAC assays for estimation antioxidant activity from guava fruit extracts. J Food Comp Anal. 19:669676.

Yang H, Wang X, Liu X, Wu J, Liu C, Gong W, Zhaos Z, Hong J, Lin D, Wang Y, Lai R. 2009. Antioxidant peptidomics reveals novel skin antioxidant system. Mol Cell Proteomics. 83:571-583.

Yin LM, Edwards MA, Lin J, Yip CM, Deber CM. 2012. Roles of hydrophobicity and charge distribution of cationic antimicrobial peptide in peptide-membrane interaction. J Biol Chem. 287:7738-7745.

Zhao HW, Zhou D, Haddad GG. 2011. Antimicrobial peptide increase tolerance to oxidant stress in Drosophila melanogaster. J Biol Chem. 286:6211-6218.

Zhao J, Zhao C, Liang G, Zhang M, Zheng J. 2013. Engineering antimicrobial peptides with improved antimicrobial and hemolytic activities. J Chem Inf Model. 53:3280-3296. 